\author{
KAROL KICZKA \\ ORCID: 0000-0002-3056-024X \\ Uniwersytet Wrocławski \\ karol.kiczka@uwr.edu.pl
}

\title{
Z zagadnień sądowoadministracyjnej kontroli administracji gospodarczej
}

\begin{abstract}
Abstrakt: Spory między przedsiębiorcami a organami administracji gospodarczej są głównie rozpoznawane przez sądy administracyjne. W pozostałym zakresie weryfikacja działań administracji gospodarczej odbywa się przed sądami powszechnymi. Kontrola sądów administracyjnych rozciąga się na zarówno stanowienie, jak i wykonywanie publicznego prawa gospodarczego. Wzorce kontroli działań administracji gospodarczej są budowane z norm Konstytucji RP, prawa unijnego oraz ustaw. Pomyślny rozwój działalności gospodarczej w państwie wymaga bezstronnej, niezależnej, niezawisłej i sprawnej władzy sądowniczej.
\end{abstract}

Słowa kluczowe: administracja gospodarcza, sądy administracyjne, kontrola.

\section{Wprowadzenie}

Pierwszym aktem ustawodawczym w dziedzinie gospodarowania w opinii Stanisława Włodyki „był francuski Ordonance des negociants et marchands z 1673 r.”. Nieingerujące dotychczas państwo rozpoczęło wówczas przejawianie zainteresowania działalnością gospodarczą przez „nasycanie” stosunków gospodarczych normami prawa wykreowanymi przez właściwe organy. Wynikiem podjętej interwencji normodawczej ze strony państwa była dająca się wyraźnie zauważyć unifikacja norm regulujących aktywność gospodarczą. Jednocześnie skutkiem

1 S. Włodyka, Prawo gospodarcze, t. 1, Warszawa 1981, s. 11; por. A. Chełmoński, Prawo gospodarcze, Warszawa 1924, s. 3; W. Małecki, Policja gospodarcza w prawie gospodarczym. Ujęcie teoretyczne, Warszawa 2019, s. 1-73. 
tego zjawiska, zdaniem Tadeusza Bigo, było „powstawanie państwowego prawa przemysłowego"2.

Zauważmy, że „nocne stróżowanie” państwa w gospodarce — jak przekonuje Cezary Kosikowski — należy już do przeszłości. Dzisiaj dba się o sprawną gospodarkę i finanse publiczne, ponieważ służą one osiąganiu celów społecznych o charakterze cywilizacyjnym, wytyczonych w formie wzorców i standardów oraz prawa $\mathrm{w}$ ramach interwencjonizmu realizowanego $\mathrm{w}$ skali międzynarodowej i unijnej. Wynika to wyraźnie, jak akcentuje C. Kosikowski, z zadań i celów, jakie stawiają sobie organizacje międzynarodowe i UE, interweniując $w$ funkcjonowanie współczesnych społeczeństw i państw ${ }^{3}$.

Dominująca część przedstawicieli doktryny szeroko rozumianego prawa gospodarczego opowiada się za celowością przyjęcia — przynajmniej na potrzeby prowadzenia badań naukowych i kształcenia w szkołach wyższych - dychotomicznego podziału tej gałęzi na prawo gospodarcze publiczne oraz prywatne ${ }^{4}$. Publiczne prawo gospodarcze w znaczącej części, jak akcentuje Teresa Rabska, wykształciło się z powszechnego prawa administracyjnego i rozwija się głównie w obszarze prawa publicznego. Konceptualizacja prowadzona jest zazwyczaj przy zastosowaniu metod i narzędzi właściwych naukom trudniącym się naświetlaniem treści prawa publicznego. Dla publicznego prawa gospodarczego szczególnie charakterystyczne są — jak trafnie zauważa badaczka — związki z naukami ekonomicznymi oraz o zarządzaniu, widocznie wyróżniające tę dyscyplinę prawną ${ }^{5}$.

Ważne miejsce norm procesowych dla jednostki (przedsiębiorcy) na płaszczyźnie prawa publicznego, w tym publicznego prawa gospodarczego, wzmiankuje Jan Jednrośka. W odróżnieniu od prawa prywatnego — jak zaznacza autor — prawo publiczne, „żyje" procedurą, albowiem w doniosłym zakresie jego stosowanie (przestrzeganie) wiąże się z działaniami administracji publicznej (admini-

2 T. Bigo, Ewolucja prawa przemystowego, „Państwo i Prawo” 1949, nr 5-6, s. 46; por. L. Bar, Władcze działania w gospodarce rynkowej (rozważania prawne), „Państwo i Prawo” 1991, nr 12, s. 22; L. Kieres, Zagadnienia wprowadzajace, [w:] A. Borkowski et al., Administracyjne prawo gospodarcze, red. L. Kieres, Wrocław 2005, s. 12.

3 C. Kosikowski, Wspótczesny interwencjonizm, Warszawa 2018, s. 19-20; por. Konstytucja gospodarcza Unii Europejskiej. Aksjologia, red. A. Nowak-Far, Warszawa 2010; B. Limperg, Zaufanie i rządy prawa, [w:] Przyszłość Europy opartej na rzadach prawa. Studia i Analizy Sądu Najwyższego. Materiaty Naukowe, t. 8, Warszawa 2019, s. 15-21.

4 J. Grabowski, Przedmiot i zakres publicznego prawa gospodarczego, [w:] J. Grabowski et al., System Prawa Administracyjnego, t. 8a. Publiczne prawo gospodarcze, red. R. Hauser, Z. Niewiadomski, A. Wróbel, Warszawa 2013, s. 22.

5 T. Rabska, Prawo administracyjne a publiczne prawo gospodarcze (kilka dyskusyjnych refleksji), [w:] Między tradycją a przyszłościa w nauce prawa administracyjnego. Księga jubileuszowa Profesora Jana Bocia, red. J. Supernat, Wrocław 2009, s. 586-587; L. Kieres, Konstytucyjne publiczne prawo gospodarcze, „Ruch Prawniczy, Ekonomiczny i Socjologiczny” 2014, nr 2, s. 191. Zob. Fenomen prawa administracyjnego. Ksiega jubileuszowa profesora Jana Zimmermanna, red. W. Jakimowicz, M. Krawczyk, Warszawa 2019. 
stracji gospodarczej). Co bowiem znaczą najlepsze rozwiązania materialnoprawne, jeżeli przedsiębiorca nie ma proceduralnych możliwości ich wykorzystania do ochrony swoich interesów? Procedura administracyjna określana jest przez J. Jendrośkę „kluczem do wolności”, który jest jednym z podstawowych elementów demokratycznego państwa prawa ${ }^{6}$.

$\mathrm{Na}$ gruncie publicznego prawa gospodarczego wzmiankowany „klucz do wolności" należy odnieść przede wszystkim do ustrojowej wolności działalności gospodarczej. Wolność działalności gospodarczej ${ }^{7}$ Adam Chełmoński zalicza do zasad ogólnych prawa publicznego ${ }^{8}$. Wolność ta zdaniem tego badacza jest specyficznym dla publicznego prawa gospodarczego zastosowaniem (odwzorowaniem) podstawowej zasady wolności człowieka wyrażonej Konstytucji RP: „Przyrodzona i niezbywalna godność człowieka stanowi źródło wolności i praw człowieka i obywatela. Jest ona nienaruszalna, a jej poszanowanie i ochrona jest obowiązkiem władz publicznych"9.

W publicznym prawie gospodarczym wolność działalności gospodarczej w jej zasadniczym rozumieniu to prawna możność podjęcia i prowadzenia działalności gospodarczej przez każdego, bez konieczności uzyskiwania na to zgody władzy publicznej ${ }^{10}$. Sprowadzona na grunt czysto jurydyczny wolność działalności gospodarczej według A. Chełmońskiego oznacza w istocie rzeczy wolność wykonywania praw majątkowych, zwłaszcza prawa własności i swobodę umów. Niemniej już u samych narodzin państwa liberalnego wiedziano, że tak szeroko pojęta wolność działalności gospodarczej nie może być w pełni urzeczywistniona i od początku uznawano, że konieczne są jej ograniczenia podyktowane ważnym interesem publicznym ${ }^{11}$.

${ }^{6}$ J. Jendrośka, Ogólne postępowanie administracyjne i sądowoadministracyjne, Wrocław 2010, s. 11; por. M. Gersdorf, Przedmowa, [w:] Przyszłość Europy..., s. 5-9.

7 Por. A. Walaszek-Pyzioł, Swoboda działalności gospodarczej, Kraków 1994; C. Kosikowski, Wolność gospodarcza w prawie polskim, Warszawa 1995; S. Biernat, A. Wasilewski, Wolność gospodarcza w Europie, Kraków 2000; Wolność gospodarcza. Acquis communautaire, red. Z. Brodecki, Warszawa 2003; M. Szydło, Swoboda prowadzenia działalności gospodarczej i swoboda świadczenia usług w prawie Unii Europejskiej, Torun 2005; idem, Swoboda działalności gospodarczej, Warszawa 2005; R. Sowiński, Wolność i ustawowa swoboda działalności gospodarczej, Wrocław 2007; J. Ciapała, Konstytucyjna wolność działalności gospodarczej w Rzeczypospolitej Polskiej, Szczecin 2009; K. Klecha, Wolność działalności gospodarczej w Konstytucji RP, Warszawa 2009; M. Szydło, Wolność działalności gospodarczej jako prawo podstawowe, Warszawa 2011; R. Biskup, Wolność gospodarcza w wymiarze podmiotowym, Lublin 2011; P. Czarnek, Wolność gospodarcza. Pierwszy filar społecznej gospodarki rynkowej, Lublin 2014; A. Szafrański, Konstytucyjna wolność gospodarcza na tle historii idei i gospodarki, Warszawa 2018.

${ }^{8}$ A. Chełmoński, Zasady ogólne prawa publicznego, [w:] A. Borkowski et al., Administracyjne prawo gospodarcze, Wrocław 2003, s. 55-56.

9 Art. 30 Konstytucji Rzeczypospolitej Polskiej z dnia 2 kwietnia 1997 roku (Dz.U. Nr 78, poz. 483 ze zm.); dalej: Konstytucja RP, Konstytucja.

10 A. Chełmoński, op. cit.

11 Ibidem. 
Celem opracowania jest analiza wybranych działań administracji gospodarczej podjętych wobec przedsiębiorców (podmiotów działalności gospodarczej) w domenie kontroli sądowoadministracyjnej. Jak wiadomo, kontrola sądów administracyjnych nie wyczerpuje całego zagadnienia kontroli administracji gospodarczej. Piśmiennictwo akcentuje, że obok schematu ogólnego postępowania administracyjnego, uzupełnionego postanowieniami proceduralnymi właściwymi danej sferze spraw gospodarczych (szczególne postępowania administracyjne), połączonego z kontrolą sądów administracyjnych, między innymi na potrzeby publicznoprawnej ochrony konkurencji wprowadzono w Polsce model orzekania określany jako hybrydowy.

Jego odrębność, zdaniem Bożeny Popowskiej, od modelu kształtowanego przez ogólne postępowanie administracyjne polega na tym, że zwłaszcza przepisy ustawy o ochronie konkurencji i konsumentów normują całe postępowanie, a właściwie trzy postępowania przed organem - Prezesem Urzędu Ochrony Konkurencji i Konsumentów - to jest wszystkie ich fazy prowadzące do wydania decyzji, łącznie ze środkami ochrony prawnej. Ich zaś struktura hybrydowa wyraża się w tym, że co do zasady postępowania te mają charakter administracyjnoprawny, lecz korzystają także z instytucji procedury cywilnoprawnej oraz procedury karnej. Badana przez B. Popowską struktura hybrydowa wyraża się też w tym, że ochronę sądową w sprawach z tego zakresu sprawuje szczególny sąd powszechny, jakim jest sąd ochrony konkurencji i konsumentów, w trybie przepisów o postępowaniu cywilnym. Przekazanie spraw z zakresu ochrony konkurencji sądowi powszechnemu powoduje, iż sąd ten nie kontroluje decyzji i postanowień Prezesa Urzędu Ochrony Konkurencji i Konsumentów pod kątem legalności, lecz rozpatruje spór między organem administracji publicznej a adresatem decyzji (postanowienia), mając kompetencje do jego merytorycznego rozstrzygnięcia ${ }^{12}$.

W toku rozważań wykorzystany zostanie właściwy materiał normatywny, dostępne orzecznictwo i literatura przedmiotu.

\section{Wybrane przejawy kontroli działań administracji gospodarczej}

Działania prawne administracji gospodarczej można analizować na różnych płaszczyznach stanowienia i stosowania prawa. Aktywność ta z punktu widzenia przedsiębiorcy, ogólnie rzecz ujmując, dotyczy podejmowania, wykonywania i zakończenia działalności gospodarczej. Zgodnie z wymogami konstytucyjnymi

12 B. Popowska, Publiczne prawo gospodarcze w płaszczyźnie proceduralnej, [w:] Nowe problemy badawcze $w$ teorii publicznego prawa gospodarczego ( $z$ uwzględnieniem samorządu terytorialnego), red. L. Kieres, Wrocław 2010, s. 215-216. 
to przede wszystkim Naczelny Sąd Administracyjny oraz inne sądy administracyjne sprawują, w zakresie określonym w ustawie, kontrolę działalności administracji publicznej. Kontrola ta obejmuje również orzekanie o zgodności z ustawami uchwał organów samorządu terytorialnego i aktów normatywnych terenowych organów administracji rządowej ${ }^{13}$.

Analiza praktyki orzeczniczej dowodzi, że swoboda gminy w zakresie tworzenia norm prawnych ustalających zasady usytuowania miejsc sprzedaży i podawania napojów alkoholowych jest ograniczona przez obowiązek realizowania celów ustawy z dnia 26 października 1982 roku o wychowaniu w trzeźwości i przeciwdziałaniu alkoholizmowi ${ }^{14}$. Wobec tego tworzenie zasad stojących w sprzeczności z zadaniami gminy postawionymi przez ustawodawcę oznacza naruszenie prawa, a przepisy prawa miejscowego nierealizujące celu wytyczonego przez ustawę są działaniami organu bez podstawy prawnej. NSA stwierdził ponadto, że z art. 12 ust. 2 u.w.t. wynika, że podawanie napojów alkoholowych nie mieści się w pojęciu sprzedaży napojów alkoholowych przeznaczonych do spożycia w miejscu sprzedaży. Wobec tego w uchwale powinny być uregulowane zarówno zasady w zakresie usytuowania punktów podawania napojów alkoholowych, jak i sprzedaży takich napojów (wyrok z 22 marca 2017 roku, sygn. II GSK 1497/15). Upoważnienie do ustalenia liczby punktów sprzedaży napojów alkoholowych, wynikające $\mathrm{z}$ art. 12 ust. 1 u.w.t., obejmuje gminę (miasto) jako całość. Określenie liczby punktów sprzedaży napojów dla poszczególnych bądź ściśle określonych terenów danej gminy jest niedopuszczalne. Podstawy do takiego działania nie daje również art. 18 ust. 1 ustawy o samorządzie gminnym (wyrok z dnia 8 czerwca 2017 roku, sygn. II GSK 4181/16) ${ }^{15}$.

Przedmiotem kontroli sądowoadministracyjnej była też między innymi działalność legislacyjna administracji rządowej. W wyroku z 19 września 2018 roku (sygn. II GSK 1271/18) NSA przyjął, że § 12 ust. 2 rozporządzenia Ministra Gospodarki z dnia 7 stycznia 2008 roku w sprawie prawnej kontroli metrologicznej przyrządów pomiarowych ${ }^{16} \mathrm{w}$ zakresie, w jakim stanowi o możliwości zatrzymania egzemplarza przyrządu pomiarowego, został wydany z przekroczeniem delegacji zawartej w art. 9 ustawy Prawo o miarach ${ }^{17}$, która w żadnym miejscu nie upoważnia ministra właściwego do spraw gospodarki do wydania regulacji stanowiącej podstawę tak dalece idącej ingerencji w prawo własności jak w niniejszej sprawie, w której na podstawie $\S 12$ ust. 2 rozporządzenia zatrzymano przyrząd spółki na okres ważności decyzji, to jest na 10 lat. Tymczasem, jak wynika $\mathrm{z}$ art. 64 ust. 3 Konstytucji RP, własność może być ograniczona tylko w drodze ustawy

13 Zob. Jednostka wobec władczej ingerencji organów administracji publicznej. Księga jubileuszowa dedykowana Profesor Barbarze Adamiak, red. J. Korczak, K. Sobieralski, Wrocław 2019.

14 Dz.U. z 2016 r. poz. 487 ze zm.; dalej: u.w.t.

15 Informacja o działalności sądów administracyjnych w 2017 roku, Warszawa 2018, s. 106.

16 Dz.U. z 2008 r. Nr 5, poz. 29 ze zm.

17 Ustawa z dnia 11 maja 2001 roku Prawo o miarach (Dz.U. z 2019 r. poz. 541 ze zm.). 
$\mathrm{i}$ jedynie $\mathrm{w}$ zakresie, $\mathrm{w}$ jakim nie narusza ona istoty prawa własności. Ponadto zgodnie z ustanowioną $\mathrm{w}$ art. 20 Konstytucji zasadą społecznej gospodarki rynkowej, stanowiącą podstawę ustroju gospodarczego Rzeczypospolitej Polskiej, jest ona oparta między innymi na wolności działalności gospodarczej oraz własności prywatnej. NSA zaaprobował stanowisko sądu pierwszej instancji o konieczności uwzględnienia przez organ w ponownie prowadzonym postępowaniu zasady proporcjonalności, jak też słusznego interesu strony wynikającego z przysługującego jej do zatrzymanego przyrządu prawa własności ${ }^{18}$.

Granice korzystania z ustrojowo gwarantowanej wolności działalności gospodarczej to zawsze aktualny odcinek styku przedsiębiorcy $\mathrm{z}$ administracją gospodarczą. W wyroku z 19 lipca 2017 roku (sygn. II GSK 2772/15) NSA stwierdził, że z art. 7 ust. 1 oraz art. 29 ust. 1 ustawy z dnia 9 czerwca 2011 roku Prawo geologiczne i górnicze ${ }^{19}$ wynika, iż organ odmawia udzielenia koncesji, gdy skutkiem prowadzonej działalności będzie uniemożliwienie wykorzystania nieruchomości zgodnie z jej przeznaczeniem. $Z$ inną sytuacją mamy do czynienia, gdy zachodzi konieczność wykorzystania konkretnej nieruchomości do wykonywania działalności górniczej. W tym wypadku przedsiębiorca wykonujący taką działalność może, na podstawie art. 18 ust. 1 p.g.g., żądać umożliwienia korzystania z nieruchomości lub jej części przez czas oznaczony, za wynagrodzeniem. Działalność określona ustawą Prawo geologiczne i górnicze nie musi być jednak, w świetle jej art. 7 ust. 1 i art. 29 ust. 1, zgodna z miejscowym planem zagospodarowania przestrzennego. Ustawa stawia bowiem jedynie wymaganie, aby działalność ta nie naruszała przeznaczenia nieruchomości ${ }^{20}$.

Tematyka uprawnień publicznoprawnych w działalności gospodarczej otrzymała nowy wymiar w wyniku przyjęcia ustawy z dnia 5 lipca 2018 roku o zarządzie sukcesyjnym przedsiębiorstwem osoby fizycznej oraz o innych ułatwieniach związanych z sukcesją przedsiębiorstw ${ }^{21}$. Judykatura akcentuje repartycje między indywidualnymi działaniami administracji w sferze gospodarczej. W wyroku z 26 lipca 2017 roku (sygn. II GSK 3169/15) NSA uznał, że w ustawie z dnia 20 czerwca 1997 roku — Prawo o ruchu drogowym ${ }^{22}$ ustawodawca rozróżnił kwestie wydania zezwolenia na przeprowadzanie badań technicznych pojazdów oraz wydania poświadczenia, o którym mowa w art. 83 ust. 3 pkt 5 p.r.d. Zezwolenie na przeprowadzanie badań technicznych pojazdów jest uprawnieniem publicznoprawnym, o charakterze osobistym, podczas gdy wzmiankowane poświadczenie zgodności może jedynie potwierdzić, czy stacja kontroli pojazdów

18 Informacja o działalności sądów administracyjnych w 2018 roku, Warszawa 2019, s. 135.

19 Dz.U. z 2015 r. poz. 196 ze zm.; dalej: p.g.g.

${ }^{20}$ Informacja o działalności sądów administracyjnych w 2017 roku..., s. 127.

21 Dz.U. z 2018 r. poz. 1629 ze zm. Zob. S. Rosmarin, Sukcesja w uprawnienia przemystowe. Studjum prawno-publiczne, Lwów 1934; R. Blicharz, Zarząd sukcesyjny przedsiębiorstwem osoby fizycznej, Warszawa 2019.

22 Dz.U. z 2012 r. poz. 1137 ze zm.; dalej: p.r.d. 
jest przygotowana lokalowo i sprzętowo do przeprowadzenia badań pojazdów. Weryfikacja tego, czy przedsiębiorca rzeczywiście spełnia warunki wymagane do prowadzenia stacji kontroli pojazdów o określonym zakresie badań następuje dopiero na etapie wykonywania tej działalności regulowanej (system kontroli ex post). Składając do starosty wniosek o wpis do rejestru, przedsiębiorca podaje dane wskazane w art. 83a ust. 3 p.r.d. oraz składa oświadczenie o treści określonej $\mathrm{w}$ art. 83 a ust. 4 p.r.d. Wnioskodawca potwierdza zatem między innymi, że ma wyposażenie kontrolno-pomiarowe oraz warunki lokalowe gwarantujące wykonywanie odpowiedniego zakresu badań technicznych pojazdów zgodnie ze szczegółowymi warunkami przeprowadzania tych badań (art. 83 ust. 3 pkt 4 p.r.d.), natomiast organ przed wydaniem poświadczenia, o którym mowa w art. 83 ust. 3 pkt 5 p.r.d., ma obowiązek sprawdzenia, czy przedsiębiorca jest uprawniony do wystąpienia $\mathrm{z}$ wnioskiem o wydanie poświadczenia ${ }^{23}$.

$\mathrm{Z}$ kolei w sprawach o cofnięcie zezwolenia na prowadzenie hurtowni farmaceutycznej na podstawie art. 81 ust. 2 z dnia 6 września 2001 roku - Prawo farmaceutyczne ${ }^{24} \mathrm{~W}$ orzecznictwie podtrzymano pogląd, iż ocena określonych tym przepisem przesłanek ma zindywidualizowany charakter i wymaga ustalenia, czy konkretny przedsiębiorca zajmujący się obrotem hurtowym produktami leczniczymi realizuje spoczywający na nim obowiązek ustawowy. Zdaniem NSA treść tego obowiązku należy postrzegać w kontekście art. 81 dyrektywy 2001/83/WE Parlamentu Europejskiego i Rady z dnia 6 listopada 2001 roku w sprawie wspólnotowego kodeksu odnoszącego się do produktów leczniczych stosowanych u ludzi. Przepis ten w brzmieniu nadanym przez art. 1 dyrektywy 2004/27/WE Parlamentu Europejskiego i Rady z dnia 31 marca 2004 roku $^{25}$ nakazuje, aby wskazane w nim podmioty, między innymi dystrybutor danego produktu leczniczego wprowadzanego do obrotu w państwie członkowskim, w granicach swych obowiązków zapewniały właściwe i stałe dostawy danego produktu leczniczego dla aptek oraz osób upoważnionych do zaopatrywania w produkty lecznicze w taki sposób, że uwzględnione są potrzeby pacjentów w danym państwie członkowskim.

Wykładnia art. $36 \mathrm{z}$ ust. 1 p.f. uwzględniająca zasady wynikające z prawa unijnego prowadzi więc do wniosku, że przedsiębiorca prowadzący hurtownię farmaceutyczną zobligowany jest do zapewnienia nieprzerwanego zaspokajania zapotrzebowania na produkty lecznicze podmiotów uprawnionych w ilości odpowiadającej potrzebom pacjentów w Polsce. W sytuacji stwierdzonego skupu leków z polskiego rynku przez prowadzącą hurtownię spółkę i sprzedaży ich do hurtowni zagranicznych na szeroką skalę obowiązek, o którym mowa, został naruszony, co uzasadniało cofnięcie zezwolenia na podstawie art. 81 ust. 2 p.f. NSA uznał, że w tej sytuacji analiza rynku, w tym tego, czy określone produkty lecz-

\footnotetext{
23 Informacja o działalności sądów administracyjnych w 2017 roku..., s. 110.

24 Dz.U. z 2016 r. poz. 2142 ze zm.; dalej: p.f.

25 Dz.Urz. UE L 136.34.
} 
nicze były w okresie objętym kontrolą dostępne na rynku krajowym w ilościach odpowiednich do zapotrzebowania pacjentów, nie jest niezbędnym elementem postępowania prowadzonego na podstawie art. 81 ust. 1 pkt 2 p.f. w zW. $\mathrm{z}$ art. 36 z ust. 1 tej ustawy. Wykazanie braku dostępności określonych produktów leczniczych w ilościach odpowiadających potrzebom pacjentów, a także występowania związku przyczynowo-skutkowego między tym brakiem a praktyką konkretnej hurtowni farmaceutycznej nie jest bowiem warunkiem sine aua non stwierdzenia, że doszło do naruszenia normy prawnej wynikającej z art. $36 \mathrm{z}$ ust. 1 p.f. (wyrok z 17 października 2018 roku, sygn. II GSK 3386/16) ${ }^{26}$.

Ochrona określonych dóbr (wartości) jest motywem przyjmowania właściwych norm prawnych między innymi w dziedzinie policji gospodarczej i reglamentacji gospodarczej. NSA, odnosząc się do oceny prawidłowości wydanej przez Prezesa Urzędu Rejestracji Produktów Leczniczych, Wyrobów Medycznych i Produktów Biobójczych decyzji o wycofaniu z obrotu i używania termometrów rtęciowych, w sytuacji dokonania powiadomienia o zamiarze dystrybucji tego wyrobu, stwierdzil, że przewidziane przepisem art. 86 ust. 1 ustawy z dnia 20 maja 2010 roku o wyrobach medycznych ${ }^{27}$ uprawnienie do wyeliminowania wyrobu z obrotu nie jest środkiem weryfikacji prawidłowości realizacji przez podmiot, który wprowadził wyrób do obrotu na terytorium Polski, obowiązku informacyjnego wynikającego z art. 58 ust. 3 omawianej ustawy, ponieważ służy temu odrębna procedura przewidziana art. 63 tego aktu prawnego. Na mocy art. 86 ust. 1 Prezes Urzędu, działając w ramach nadzoru nad wyrobami wytwarzanymi i wprowadzanymi do obrotu, używania lub przekazanymi do oceny działania na terytorium RP, umocowany jest do wycofania $\mathrm{z}$ obrotu lub używania wyrobu w celu ochrony życia, zdrowia lub bezpieczeństwa pacjentów, użytkowników bądź innych osób albo przeciwdziałania takim zagrożeniom. Ustawodawca nie przewidział ograniczeń, które skutkowałyby wyłączeniem możliwości podjęcia przewidzianych wskazanym przepisem działań nadzorczych, czy to ze względu na upływ czasu od wprowadzenia wyrobów do obrotu, czy na dokonanie powiadomienia. Prawidłowa interpretacja art. 86 ust. 1 ustawy o wyrobach medycznych pozwala organowi nadzoru na zastosowanie odpowiednich środków zaradczych, $\mathrm{w}$ tym wyeliminowanie $\mathrm{z}$ obrotu wyrobu, zawsze gdy wymaga tego ochrona dóbr w tym przepisie wymienionych — niezależnie od tego, czy i kiedy wyrób został poddany procedurze powiadomienia oraz czy procedura ta przebiegała w sposób prawidłowy (wyrok z 19 września 2018 roku, sygn. II GSK 2834/16) ${ }^{28}$.

Analiza orzecznictwa sądowego wskazuje, że publiczne prawo gospodarcze oczekuje określonych działań od przedsiębiorcy (pracodawcy) w zakresie organizacji wewnętrznej oraz $\mathrm{w}$ relacjach $\mathrm{z}$ personelem (pracownikami) przedsiębior-

\footnotetext{
26 Informacja o działalności sądów administracyjnych w 2018 roku..., s. 111-112.

27 Dz.U. z 2010 r. Nr 107, poz. 679 ze zm.

28 Informacja o działalności sądów administracyjnych w 2018 roku..., s. 110.
} 
stwa. W wielu orzeczeniach NSA odniósł się do zagadnienia odpowiedzialności przedsiębiorcy za działania kierowcy. Wskazywano, że art. 92c ust. 1 ustawy o transporcie drogowym ${ }^{29}$ - jako wyjątek od zasady odpowiedzialności przedsiębiorcy także za działania swoich kierowców — nie tylko odnosi się do wyjątkowych sytuacji, których doświadczony i profesjonalny podmiot wykonujący przewóz drogowy, przy zachowaniu najwyższej staranności i przezorności, nie był w stanie przewidzieć, lecz dotyczy także okoliczności, których istnienia organ — bez wskazania strony - nie zna. Sprawą przedsiębiorcy (przewoźnika) jest zatem wprowadzenie takich organizacyjnych rozwiązań, które będą dyscyplinować osoby wykonujące na jego rzecz usługi kierowania pojazdem i eliminować naruszenia. Przedsiębiorca ma możliwość reagowania na działania osób, którymi posługuje się przy wykonywaniu transportu drogowego, między innymi przez bieżącą kontrolę dokumentacji obrazującej czas pracy kierowcy i stosowanie w wypadku stwierdzenia naruszeń właściwych środków dyscyplinujących (NSA na przykład w wyrokach w sprawach II GSK 830/16, II GSK 2818/16) $)^{30}$.

\section{Wnioski}

Przegląd praktyki orzeczniczej sądów administracyjnych potwierdza, że spory między przedsiębiorcami a organami działającymi w imieniu władzy publicznej są rozpoznawane zwłaszcza przez sądy administracyjne. W zakresie postępowań określanych w piśmiennictwie mianem hybrydowych weryfikacja działań administracji gospodarczej odbywa się przed sądami powszechnymi. Jak wykazuje analiza przytoczonych judykatów, rozważana kontrola rozciąga się na zarówno tworzenie (stanowienie), jak i wykonywanie (stosowanie) publicznego prawa gospodarczego. Konstruowane przez milcząca władzę „,wzorce kontroli” działań administracji gospodarczej, odnoszące się do postępowań („,procedury”) oraz ich wyniku (zazwyczaj decyzji administracyjnych), są zazwyczaj budowane z norm Konstytucji RP, prawa unijnego oraz ustaw. Zrealizowany ogląd orzecznictwa pozwala stwierdzić, że kontroli sądów administracyjnych podlega istotna część publicznego prawa gospodarczego, w tym między innymi materie tworzenie prawa, korzystania z wolności działalności gospodarczej, uprawnień do wykonywania działalności gospodarczej czy policji gospodarczej.

Swoistość kontroli aktywności administracji publicznej, w tym administracji gospodarczej sprawowanej przez sądy administracyjne, trafnie wyraził Pierwszy Prezes Najwyższego Trybunału Administracyjnego Bronisław Hełczyński:

29 Ustawa z dnia 6 września 2001 roku o transporcie drogowym (Dz.U. z 2013 r. poz. 1414 ze zm.); dalej: u.t.d.

30 Informacja o działalności sądów administracyjnych w 2017 roku..., s. 134. 
istotą każdej ze spraw jest zawsze jedno naczelne zagadnienie: stosunek jednostki do zbiorowości [...]. Trybunał orzeka o danym konkretnym stosunku życiowym w sposób ostateczny. Uznając, że dane orzeczenie czy zarządzenie było nielegalne, stwierdza, że granice swobody jednostki zostały bezzasadnie ścieśnione lub że jej prawa zostały naruszone ${ }^{31}$.

Pomyślny rozwój biznesu (działalności gospodarczej) wymaga bezstronnej, niezależnej, niezawisłej i sprawnej władzy sądowniczej do właściwej oceny działań władz administracyjnych w domenie gospodarowania.

\section{Bibliografia}

Bar L., Władcze działania w gospodarce rynkowej (rozważania prawne), „Państwo i Prawo” 1991, nr 12.

Biernat S., Wasilewski A., Wolność gospodarcza w Europie, Kraków 2000.

Bigo T., Ewolucja prawa przemysłowego, „Państwo i Prawo” 1949, nr 5-6.

Biskup R., Wolność gospodarcza w wymiarze podmiotowym, Lublin 2011.

Blicharz R., Zarząd sukcesyjny przedsiębiorstwem osoby fizycznej, Warszawa 2019.

Chełmoński A., Prawo gospodarcze, Warszawa 1924.

Chełmoński A., Zasady ogólne prawa publicznego, [w:] A. Borkowski, A. Chełmoński, M. Guziński, K. Kiczka, L. Kieres, T. Kocowski, Administracyjne prawo gospodarcze, Wrocław 2003.

Ciapała J., Konstytucyjna wolność działalności gospodarczej w Rzeczypospolitej Polskiej, Szczecin 2009.

Czarnek P., Wolność gospodarcza. Pierwszy filar społecznej gospodarki rynkowej, Lublin 2014.

Fenomen prawa administracyjnego. Ksiegga jubileuszowa profesora Jana Zimmermanna, red. W. Jakimowicz, M. Krawczyk, Warszawa 2019.

Gersdorf M., Przedmowa, [w:] Przyszłość Europy opartej na rzadach prawa. Studia i Analizy Sadu Najwyższego. Materiały Naukowe, t. 8, Warszawa 2019.

Grabowski J., Przedmiot i zakres publicznego prawa gospodarczego, [w:] J. Grabowski, L. Kieres, A. Walaszek-Pyzioł, M. Biliński, R. Blicharz, T. Długosz, K. Horubski, K. Kiczka, T. Kocowski, M. Szydło, A. Żurawik, System Prawa Administracyjnego, t. 8a. Publiczne prawo gospodarcze, red. R. Hauser, Z. Niewiadomski, A. Wróbel, Warszawa 2013.

Jednostka wobec władczej ingerencji organów administracji publicznej. Księga jubileuszowa dedykowana Profesor Barbarze Adamiak, red. J. Korczak, K. Sobieralski, Wrocław 2019.

Jendrośka J., Ogólne postępowanie administracyjne i sądowoadministracyjne, Wrocław 2010.

Kieres L., Konstytucyjne publiczne prawo gospodarcze, „Ruch Prawniczy, Ekonomiczny i Socjologiczny" 2014, nr 2.

Kieres L., Zagadnienia wprowadzające, [w:] A. Borkowski, A. Chełmoński, M. Guziński, K. Kiczka, L. Kieres, T. Kocowski, Administracyjne prawo gospodarcze, red. L. Kieres, Wrocław 2005.

Klecha K., Wolność działalności gospodarczej w Konstytucji RP, Warszawa 2009.

Konstytucja gospodarcza Unii Europejskiej. Aksjologia, red. A. Nowak-Far, Warszawa 2010.

Kosikowski C., Wolność gospodarcza w prawie polskim, Warszawa 1995.

Kosikowski C., Wspótczesny interwencjonizm, Warszawa 2018.

31 Ibidem, s. 12; por. M. Safjan, Rządy prawa a przyszłość Europy, [w:] Przyszłość Europy..., s. $28-43$.

Prawo 329, 2020

(C) for this edition by CNS 
Limperg B., Zaufanie i rządy prawa, [w:] Przyszłość Europy opartej na rzadach prawa. Studia i Analizy Sadu Najwyższego. Materiaty Naukowe, t. 8, Warszawa 2019.

Małecki W., Policja gospodarcza w prawie gospodarczym. Ujęcie teoretyczne, Warszawa 2019.

Popowska B., Publiczne prawo gospodarcze w plaszczyźnie proceduralnej, [w:] Nowe problemy badawcze $w$ teorii publicznego prawa gospodarczego (z uwzględnieniem samorzadu terytorialnego), red. L. Kieres, Wrocław 2010.

Rabska T., Prawo administracyjne a publiczne prawo gospodarcze (kilka dyskusyjnych refleksji), [w:] Między tradycją a przyszłościa w nauce prawa administracyjnego. Księga jubileuszowa Profesora Jana Bocia, red. J. Supernat, Wrocław 2009.

Rosmarin S., Sukcesja w uprawnienia przemysłowe. Studjum prawno-publiczne, Lwów 1934.

Safjan M., Rzady prawa a przyszłość Europy, [w:] Przyszłość Europy opartej na rządach prawa. Studia i Analizy Sąu Najwyższego. Materiaty Naukowe, t. 8, Warszawa 2019.

Sowiński R., Wolność i ustawowa swoboda działalności gospodarczej, Wrocław 2007.

Szafrański A., Konstytucyjna wolność gospodarcza na tle historii idei i gospodarki, Warszawa 2018. Szydło M., Swoboda działalności gospodarczej, Warszawa 2005.

Szydło M., Swoboda prowadzenia działalności gospodarczej i swoboda świadczenia usług w prawie Unii Europejskiej, Torun 2005.

Szydło M., Wolność działalności gospodarczej jako prawo podstawowe, Warszawa 2011.

Walaszek-Pyzioł A., Swoboda działalności gospodarczej, Kraków 1994.

Włodyka S., Prawo gospodarcze, t. 1, Warszawa 1981.

Wolność gospodarcza. Acquis communautaire, red. Z. Brodecki, Warszawa 2003.

\title{
On the issues of court-administrative control of economic administration
}

\begin{abstract}
Summary
Disputes between entrepreneurs and economic administration bodies are mainly heard by administrative courts. In the remaining scope, the verification of economic administration activities takes place before ordinary courts. This court-administrative control extends to both the making and enforcement of public economic law. Control patterns of economic administration activities are built from the following standards: the Polish Constitution, EU law, and parliamentary legislation. The successful development of economic activity requires an impartial, independent, and efficient judicial authority.
\end{abstract}

Keywords: economic administration, administrative courts, control.

Prawo 329, 2020

(C) for this edition by CNS 